\title{
HUBUNGAN KARAKTERISTIK PEKERJA SEKS KOMERSIL (PSK) DENGAN TINGKAT PENGETAHUAN TENTANG HIV/AIDS DI STASIUN PONCOL KOTA SEMARANG
}

\author{
Lisa Ardiningtyas ${ }^{1}$, Sawitry ${ }^{2}$ \\ ${ }^{1,2}$ Prodi Kebidanan, STIKes Karya Husada Semarang \\ E-mail : weet.ibnu@yahoo.com
}

\begin{abstract}
Abstrak
Latar Belakang Penyakit HIV/AIDS telah menyita perhatian berbagai kalangan, tidak hanya yang terkait dengan domain kesehatan saja. Kasus penyakit yang menyerang sistem kekebalan ini, di Indonesia senantiasa meningkat dari tahun ke tahun. Angka yang dirilis oleh ditjen PP\&PL Kemenkes RI menyebutkan bahwa kasus HIV tahun 2011 (Januari samapai dengan September) tercatat sebanyak 15.589 kasus, sedangkan kasus AIDS sebanyak 1.805,sedangkan di Jawa Tengah menempati urutan pertama dengan penderita AIDS sebanyak 373 orang dengan jumlah akumulasi AIDS sebanyak 1315 orang dan kasus HIV sebanyak 877 orang dengan jumlah akumulasi HIV sebanyak 2.400, dan di kota Semarang dilaporkan data akumulasi kasus AIDS sebanyak 197 orang dan HIV sebanyak 769. Jumlah kasus AIDS menurut pekerjaan penjaja seks sebanyak 681 orang, terdapat 57\% PSK lokalisasi dan 68\% PSK jalanan.Tujuan: menganalisa hubungan karakteristik PSK dengan tingkat pengetahuan tentang HIV/AIDS di stasiun Poncol Semarang. Metode: Jenis penelitian korelasional menggunakan pendekatan cross sectional dengan jumlah 37 sampel responden. Uji hubungan antar variabel dalam penelitian ini menggunakan uji chi Square. Hasil: sebagian besar PSK berumur 21-36 tahun sebanyak 25 orang $(67,6 \%)$, tingkat pendidikan sebagian besar PSK berpendidikan SD/SMP sebanyak 18 PSK (48,6\%), sosial ekonomi sebagian besar PSK berpendapatan < Rp. 991.500 yaitu 26 (70,3\%), dan 18 PSK (48,5\%) berpengetahuan kurang. Dari uji chi square diperoleh hasil ada hubungan antara karakteristik PSK dengan tingakat pengetahuan tentang HIV/AIDS.Saran: hasil penelitian tersebut diharapkan responden untuk melakukan pemeriksaan rutin ke tempat pelayanan kesehatan terdekat.
\end{abstract}

Kata Kunci: Karakteristik; Pengetahua; , HIVIAIDS

\section{CORRELATION CHARACTERISTICS OF COMMERCIAL SEX WORKERS WITH KNOWLEDGE OF HIV/AIDS IN PONCOL STATION SEMARANG CITY}

\begin{abstract}
Introduction Background HIV / AIDS has seized the attention of various circles, not only related to the health domain only. Cases of a disease that attacks the immune system is, in Indonesia constantly increasing from year to year. Figures released by the directorate general PP \& PL Strathmore University states that HIV cases in 2011 (January samapai to September) there were 15589 cases, while as many as 1805 cases of AIDS. While in Central Java topped the list with as many as 373 people with AIDS with cumulative total of 1315 people AIDS and HIV cases as many as 877 people with cumulative total of $2400 \mathrm{HIV}$, and in the city of Semarang accumulated data are reported as many as 197 cases of AIDS and HIV as many as 769 people. The number of AIDS cases by sex workers work as many as 681 people, there were $57 \%$ and $68 \%$ localization PSK PSK streets. Purpose to analyze correlation characteristic of comercial sex workers with knowledge of HIV/AIDS in Poncol Station Semarang City. Method This type of correlational studies using cross sectional approach by the number of 37 samples of respondents. Test of relationship between variables in this study using the chi Square. Result the majority of 21-36 year-old prostitute as many as 25 people (67.6\%), level of education most educated prostitutes SD / SMP as much as 18 prostitutes (48.6\%), mostly socioeconomic PSK income <USD . 991500 ie 26 (70.3\%), and 18 sex workers (48.5\%) are less knowledgeable. Obtained from the chi square test result there is a relationship between the characteristics of PSK with tingakat knowledge about HIV / AIDS. Suggestion From the results of these studies are expected to conduct routine checks of respondents to the nearest health centers.
\end{abstract}

Keywords: characteristics; knowledge; HIV / AIDS 


\section{Pendahuluan}

Acquired immune deficiency syndrom (AIDS) didefinisikan sebagai suatu kumpulan gejala penyakit kerusakan sistem kekebalan tubuh; bukan penyakit bawaan tetapi didapat dari hasil penularan. Penyakit ini disebabkan oleh human immunodeficiency virus (HIV) dan sampai saat ini belum ditemukan vaksin atau obat yang relatif efektif untuk AIDS sehingga menimbulkan keresahan di dunia (Widoyono 2008: 83).

Penyebaran virus ini pada prinsipnya secara seksual baik hetero maupun homoseksual. Selain itu penyebaran juga dapat terjadi langsung melalui darah ataupun produk darah, seperti pada pengguna narkotik intravena atau transfusi darah. (Pringgoutomo S, Himawan S, Tjarta A 2002: 127).

Permasalahan ini tidak dapat dipungkiri bertalian dengan mobilitas penduduk yang meningkat pesat yang disertai peningkatan perilaku seksual yang tidak aman dan penggunaan NAPZA (Narkotika, Psikotropika dan Zat Adiktif) suntik yang semakin luas (Profil Kesehatan Jateng 2007; 35).Penyakit yang membuat daya tahan tubuh menurun itu, kebanyakan menyerang para pekerja seks komersial. (Gusmus, 2007).

Penyakit HIV/AIDS yang menyerang sistem kekebalan ini, di Indonesia senantiasa meningkat dari tahun ke tahun. Angka yang dirilis oleh ditjen PP\&PL Kemenkes RI menyebutkan bahwa kasus HIV tahun 2011 (Januari samapai dengan September) tercatat sebanyak 15.589 kasus, sedangkan kasus AIDS sebanyak 1.805. Sedangkan di Jawa Tengah menempati urutan pertama dengan penderita AIDS sebanyak 373 orang dengan jumlah akumulasi AIDS sebanyak 1315 orang dan kasus HIV sebanyak 877 orang dengan jumlah akumulasi HIV sebanyak 2.400 orang (Ditjen PP\&PL Kemenkes RI, 2011).

Direktorat Jendral Pemberantasan Penyakit Menular dan Penyakit Lingkungan (Ditjen PPM dan PL) pada tahun 2011 melaksanakan penelitian dimana prevalensi IMS (Infeksi Menular Seksual) di Jawa Tengah, khususnya di kota Semarang dilaporkan data akumulasi kasus AIDS sebanyak 197 orang dan HIV sebanyak 769. Jumlah kasus AIDS menurut pekerjaan penjaja seks sebanyak 681 orang, terdapat 57\% PSK lokalisasi dan $68 \%$ PSK jalanan yang terinfeksi lebih dari 1 Infeksi Saluran Reproduksi (ISR) pada wanita.(Ditjen PP\&PL Kemenkes RI).

Studi pendahuluan yang dilakukan pada tanggal 12 Januari 2012 di Stasiun Poncol Kota Semarang, melalui wawancara terhadap Pekerja Seks Komersil (PSK) tentang pengetahuan HIV/AIDS ternyata dari 10 PSK hanya 2 yang dapat menjawab pertanyaan dengan benar. Selain itu, dari hasil wawancara didapatkan data karakteristik berdasarkan umur yaitu remaja 
(13-20 tahun) sebanyak 3 orang, dewasa awal (21-35 tahun) sebanyak 5 orang dan dewasa akhir (36-45 tahun) sebanyak 2 orang, sedangkan untuk karakteristik sosial ekonomi ada 8 orang dengan penghasilan dibawah UMR $(<\mathrm{Rp} .991 .500,00)$ dan 2 orang dengan penghasilan diatas UMR ( $\geq$ Rp. 991.500,00).

\section{Tinjauan Teoritis}

HIV (human immunodeficiency virus) adalah sebuah retrovirus yang menginfeksi sel sistem kekebalan tubuh manusia - terutama CD4+ Sel T dan macrophage, komponen vital dari sistem sistem kekebalan tubuh "tuan rumah" - dan menghancurkan atau merusak fungsi mereka. Infeksi dari HIV menyebabkan pengurangan cepat dari sistem kekebalan tubuh, yang menyebabkan kekurangan imun. HIV merupakan penyebab dasar AIDS.( Hasibuan S. 2006)

Acquired Immune Deficiency Syndrome (disingkat AIDS) adalah sekumpulan gejala dan infeksi (atau: sindrom) yang timbul karena rusaknya sistem kekebalan tubuh manusia akibat infeksi virus HIV; atau infeksi virus-virus lain yang mirip yang menyerang spesies lainnya (SIV, FIV, dan lain-lain).

HIV dan virus-virus sejenisnya umumnya ditularkan melalui kontak langsung antara lapisan kulit dalam (membran mukosa) atau aliran darah, dengan cairan tubuh yang mengandung HIV, seperti darah, air mani, cairan vagina, cairan preseminal, dan air susu ibu. Penularan dapat terjadi melalui hubungan intim (vaginal, anal, ataupun oral), transfusi darah, jarum suntik yang terkontaminasi, antara ibu dan bayi selama kehamilan, bersalin, atau menyusui, serta bentuk kontak lainnya dengan cairan-cairan tubuh tersebut.( Nasronudin. 2007)

\section{Metode Penelitian}

Jenis penelitian korelasional dengan pendekatan cross sectional. Penelitian ini dilaksanakan pada bulan Januari - Agustus 2012, Populasi dalam penelitian ini adalah Pekerja Seks Komersial (PSK) di Stasiun Poncol Semarang yang berjumlah 58 orang PSK sedangkan sampel yang diambil di Stasiun Poncol Kota Semarang adalah 37 Pekerja Seks Komersil (PSK) Jalanan. Analisa data menggunakan uji Chi Square. 


\section{Hasil Penelitian}

1. Hubungan Antara Umur Dengan Tingkat Pengetahuan PSK Tentang HIV/AIDS

Tabel 1 Hubungan Antara Umur Dengan Tingkat Pengetahuan

\begin{tabular}{c|c|c|c|c|c|c|c}
\hline \multirow{2}{*}{$\begin{array}{c}\text { Kategori } \\
\text { Umur }\end{array}$} & \multicolumn{4}{|c|}{ Tingkat Pengetahuan } & \multicolumn{2}{|c|}{ Total } & \multirow{2}{*}{$\rho$ value } \\
\cline { 2 - 7 } & \multicolumn{2}{|c|}{ Kurang } & \multicolumn{2}{c|}{ Cukup/Baik } & \multicolumn{2}{|c}{} & \\
\cline { 2 - 7 } & $\mathrm{n}$ & $\%$ & $\mathrm{n}$ & $\%$ & $\mathrm{n}$ & $\%$ & \\
\hline $13-20$ & 9 & 90 & 1 & 10 & 10 & 100 & \multirow{2}{*}{0,002} \\
\hline $21-35 / 36-45$ & 9 & 33,3 & 18 & 66,7 & 27 & 100 & \\
\hline Total & 18 & 48,6 & 19 & 51,4 & 37 & 100 & \\
\hline
\end{tabular}

Dari tabel 1 diatas dapat diketahui bahwa PSK dengan umur 13-20 tahun dengan tingkat pengetahuan kurang sebanyak 9 responden (90\%) dan tingkat pengetahuan cukup/baik sebanyak 1 responden (10\%). Umur 21-35/36-45 tahun dengan tingkat pengetahuan kurang sebanyak 9 responden (33,3\%), tingkat pengetahuan cukup/baik sebanyak 18 responden $(66,7 \%)$.

Hasil uji statistik chi square diperoleh nilai $\rho \quad 0,021$ dengan demikian $\rho$ value lebih kecil dari $\alpha 0,05(0,002<0,05)$ sehingga Ho ditolak dan Ha diterima. Hal ini berarti bahwa ada hubungan antara umur dengan tingkat pengetahuan PSK tentang HIV/AIDS.

2. Hubungan Antara Pendidikan Dengan Tingkat Pengetahuan Tentang PSK Tentang HIV/AIDS

Tabel 2 Hubungan Antara Pendidikan Dengan Tingkat Pengetahuan

\begin{tabular}{|c|c|c|c|c|c|c|c|}
\hline \multirow{3}{*}{$\begin{array}{c}\text { Kategori } \\
\text { Pendidikan }\end{array}$} & \multicolumn{4}{|c|}{ Tingkat Pengetahuan } & \multirow{2}{*}{\multicolumn{2}{|c|}{ Total }} & \multirow{3}{*}{$\rho$ value } \\
\hline & \multicolumn{2}{|c|}{ Kurang } & \multicolumn{2}{|c|}{ Cukup/Baik } & & & \\
\hline & $\mathrm{N}$ & $\%$ & $\mathrm{n}$ & $\%$ & $\mathrm{~N}$ & $\%$ & \\
\hline SD/SMP & 12 & 66,7 & 6 & 33,3 & 18 & 100 & 0032 \\
\hline SMA/PT & 6 & 31,6 & 13 & 68,4 & 19 & 100 & 0,033 \\
\hline Total & 18 & 48,6 & 19 & 51,4 & 37 & 100 & \\
\hline
\end{tabular}

Dari tabel 2 diatas dapat diketahui bahwa PSK dengan pendidikan SD/SMP dengan tingkat pengetahuan kurang sebanyak 12 responden $(66,7 \%)$ dan tingkat pengetahuan cukup/baik sebanyak 6 responden (33,3\%). Pendidikan SMA/PT dengan tingkat pengetahuan kurang sebanyak 6 responden $(31,6 \%)$, tingkat pengetahuan cukup/baik sebanyak 13 responden $(68,4 \%)$.

Hasil uji statistik chi square diperoleh nilai $\rho \quad 0,033$ dengan demikian $\rho$ value lebih kecil dari $\alpha 0,05(0,033<0,05)$ sehingga Ho ditolak dan Ha diterima. Hal ini 
berarti bahwa ada hubungan antara pendidikan dengan tingkat pengetahuan PSK tentang HIV/AIDS.

3. Hubungan Antara Sosial Ekonomi Dengan Tingkat Pengetahuan PSK Tentang HIV/AIDS

Tabel 3 Hubungan Silang Antara Sosial Ekonomi Dengan Tingkat Pendidikan

\begin{tabular}{c|c|c|c|c|c|c|c}
\hline \multirow{2}{*}{$\begin{array}{c}\text { Kategori } \\
\text { Umur }\end{array}$} & \multicolumn{4}{|c|}{ Tingkat Pengetahuan } & \multirow{2}{*}{ Total } & \multirow{2}{*}{$\rho$ value } \\
\cline { 2 - 7 } & \multicolumn{2}{|c|}{ Kurang } & \multicolumn{2}{c|}{ Cukup/Baik } & \multicolumn{2}{c}{} & \\
\cline { 2 - 7 } & $\mathrm{n}$ & $\%$ & $\mathrm{n}$ & $\%$ & $\mathrm{n}$ & $\%$ & \\
\hline$<$ Rp.991.500 & 17 & 65,4 & 9 & 34,6 & 26 & 100 & \multirow{2}{*}{0,002} \\
\hline Rp.991.500 & 1 & 9,1 & 10 & 90,9 & 11 & 100 & \\
\hline Total & 18 & 48,6 & 19 & 51,4 & 37 & 100 & \\
\hline
\end{tabular}

Dari tabel 3 diatas dapat diketahui bahwa PSK dengan pendapatan dibawah UMR (<Rp.991.500) dengan tingkat pengetahuan kurang sebanyak 17 responden $(65,4 \%)$, tingkat pengetahuan cukup/baik sebanyak 9 responden $(34,6 \%)$. Pendapatan diatas UMR ( Rp.991.500) dengan tingkat pengetahuan kurang sebanyak 1 responden $(9,1 \%)$, tingkat pengetahuan cukup/baik sebanyak 10 responden $(90,9 \%)$.

Hasil uji statistik chi square diperoleh nilai $\rho \quad 0,002$ dengan demikian $\rho$ value lebih kecil dari $\alpha$ 0,05 $(0,002<0,05)$ sehingga Ho ditolak dan Ha diterima. Hal ini berarti bahwa ada hubungan antara soaial ekonomi dengan tingkat pengetahuan PSK tentang HIV/AIDS.

\section{Pembahasan}

1. Hubungan Antara Umur Dengan Tingkat Pengetahuan PSK Tentang HIV/AIDS

Pada penelitian ini dapat diketahui bahwa sebagian besar responden berumur 2135/36-45 tahun (66,7\%), umur responden termasuk pada umur dewasa awal dimana responden memiliki tingkat pengetahuan yang cukup/baik. Hasil uji statistik Pearson Chi Square diperoleh nilai $\rho \quad 0,002$ dengan demikian $\rho$ value lebih kecil dari $\alpha 0,05$ $(0,002<0,05)$ sehingga Ho ditolak dan Ha diterima. Hal ini berarti bahwa ada hubungan antara umur dengan tingkat pengetahuan PSK tentang HIV/AIDS.

Hal ini sesuai dengan Efendi (2009) menunjukkan bahwa salah satu faktor yang mempengaruhi pengetahuan adalah usia. Usia mempengaruhi terhadap daya tangkap dan pola pikir seseorang.

Pernyataan tersebut menunjukkan bahwa dengan umur responden yang berumur reproduksi memiliki pengetahuan kurang ini dikarenakan bukan hanya umur yang 
mempengaruhi tingkat pengetahuan PSK tentang HIV/AIDS melainkan ada faktor lain yang mempengaruhi tingkat pengetahuan PSK yaitu taraf pendidikan yang rendah, informasi, dan pengalaman yang kurang.

2. Hubungan Antara Pendidikan Dengan Tingkat Pengetahuan PSK Tentang HIV/AIDS

Pada penelitian ini dapat diketahui bahwa sebagian besar responden tingkat pendidikannya SD/SMP $18(48,6 \%)$, pendidikan responden termasuk pada pendidikan dasar hal ini sesuai dengan tingkat pengetahuan responden yang cukup/baik. Hasil uji statistik Pearson Chi Square diperoleh nilai $\rho$ 0,033 dengan demikian $\rho$ value lebih kecil dari $\alpha$ 0,05 $(0,033<0,05)$ sehingga Ho ditolak dan Ha diterima. Hal ini berarti bahwa ada hubungan antara pendidikan dengan tingkat pengetahuan PSK tentang HIV/AIDS.

Menurut Notoatmodjo (2003) bahwa orang yang berpendidikan tinggi akan memberikan respon yang rasional terhadap informasi yang datang.

Pendidikan PSK yang sebagian besar SD/SMP ini menyebabkan responden memiliki pengetahuan yang kurang karena tingkat pendidikan seseorang akan berpengaruh terhadap sesuatu yang datang dari luar. Orang yang berpendidikan tinggi akan memberikan respon yang lebih rasional terhadap informasi yang datang dan akan berfikir sejauh mana keuntungan yang mungkin diperoleh dari gagasan tersebut.

Pengetahuan yang benar dapat memimpin seseorang ke arah perilaku seksual yang rasional, bertanggung jawab dan dapat membantu membuat keputusan pribadi yang penting tentang seksualitas. Sebaliknya pengetahuan yang salah dapat mengakibatkan persepsi yang salah tentang seksualitas sehingga selanjutnya akan menimbulkan perilaku seksual yang salah dengan segala akibatnya (Martaadisoebrata,2005; h.65).

3. Hubungan Antara Sosial Ekonomi Dengan Tingkat Pengetahuan PSK Tentang HIV/AIDS

Pada penelitian ini dapat diketahui bahwa sebagian besar responden memiliki penghasilan dibawah UMR kota semarang Rp. 991.500 sebanyak 26 (70,3\%). Hasil uji statistik Pearson Chi Square diperoleh nilai $\rho$ 0,002 dengan demikian $\rho$ value lebih kecil dari $\alpha 0,05(0,002<0,05)$ sehingga Ho ditolak dan Ha diterima. Hal ini berarti bahwa ada hubungan antara sosial ekonomi dengan tingkat pengetahuan PSK tentang HIV/AIDS.

Kondisi kemiskinan ini disebabkan oleh beberapa faktor diantaranya, rendahnya taraf pendidikan, rendahnya derajat kesehatan, terbatasnya lapangan pekerjaan dan kondisi terisolasi. (Subburatno,2004). 
Hasil penelitian merangkum bahwa pendapatan perbulan PSK di Stasiun Poncol sebagian besar kurang daru UMR kota semarang yaitu Rp.991.500, sedangkan mereka butuh penghasilan lebih banyak untuk mencukupi kebutuhan, maka mereka memilih menjadi PSK.

\section{Kesimpulan}

1. Karakteristik responden berdasarkan umur sebagian besar berumur 21-35 tahun, berdasarkan tingkat pendidikan sebagian besar berpendidikan SD/SMP dan berdasarkan sosial ekonomi sebagian besar berpendapatan dibawah UMR kota semarang Rp.991.500.

2. Tingkat pengetahuan responden tentang HIV/AIDS sebagian besar berpengetahuan kurang.

3. Ada hubungan karakteristik PSK dengan tingkat pengetahuan PSK tentang HIV/AIDS.

\section{Saran}

1. Bagi Responden

Diharapkan untuk melakukan pemeriksaan rutin ke tempat pelayanan kesehatan terdekat.

2. Bagi Tenaga Kesehatan

Bagi tenaga kesehatan diharapkan untuk dapat meningkatkan kualitas penyuluhan tentang HIV/AIDS agar para PSK mengetahui bahaya dan resiko yang ditimbulkan HIV/AIDS dan melakukan pemeriksaan rutin terhadap PSK.

\section{Daftar Referensi}

Arikunto, Suharsimi. 2006. Prosedur Penelitian Suatu Pendekatan Praktik. Jakarta : Rineka Cipta.

BKKBN . 2003. Penanggulangan Masalah Kesehatan Reproduksi. Jakarta: BKKBN. . 2003. Serba Serbi HIV/AIDS. Jakarta: BKKBN.

2008. Buku pedoman konseling kesehatan reproduksi remaja (KRR). Jakarta: BKKBN.

Budiarto E. 2002. Biostatistika Untuk Kedokteran \& Kesehatan Masyarakat. Jakarta: EGC. 
Budimulja U. 2002. Acquired Immune Deficiency Syndrom (AIDS). Dalam: Djuanda A, Hamzah M, Aisah S, editor. Ilmu Penyakit Kulit dan Kelamin. Jakarta: FKUI.

Casey K M M. 2002. Human Immunodeficiency Virus/Sindrom Imunodefisiensi Didapat (AIDS, Acquired Immunodeficiency Syndrome). Dalam: Price S A, Wilson L M. Patofisiologi Konsep Klinis Proses-Proses Penyakit. Jakarta: EGC.

Glasier A, Gebbie A. 2006. Keluarga berencana dan kesehatan repsoduksi. Edisi keempat. Jakarta: EGC.

Harahap dan Lita. 2004. "Pengaruh Peer Education Terhadap Pengetahuan dan Sikap Mahasiswa Dalam Menanggulangi HIV-AIDS di Universitas Sumatra Utara”, (Online), (http://www.Pengaruh_Peer_Education.html/, diakses tanggal 25 Desember 2011).

Hasibuan S. 2006. "Prostitusi Sebagai Penyakit Sosial dan Problematika Penegakan Hukum”, (Online), (http://library.usu.ac.id/download/fh/pidana-syafruddin5.pdf/, diakses tanggal 27 Desember 2011).

Hawari D. 2004. Global Effect HIV/AIDS Dimensi Psikoreligi. Jakarta: Balai Penerbit FKUI.

Hidayat A, Aziz Alimul. 2007. Metodologi penelitian kebidanan dan teknik analisis data. Jakarta: Salemba Medika.

Hutapea R. 2003. AIDS \& PMS dan Perkosaan. Jakarta: Rienika Cipta.

Mandal B K, Wilkins E G L, Dunbar E M, Mayon-white R T. 2008. Lecture Notes Penyakit Infeksi. Jakarta: Erlangga.

Mardalis. 2009. Metode penelitian suatu pendekatan proposal. Jakarta: Bumi Aksara.

Nasronudin. 2007. HIV \& AIDS. Surabaya: Airlangga University Press.

Noor N N. 2008. Epidemiologi. Jakarta: Rineka Cipta.

Notoatmodjo S. 2005. Metodologi penelitian kesehatan. Jakarta: Rineka Cipta. . 2010. Metodologi penelitian kesehatan. Jakarta: Rineka Cipta.

Novrial D, Suyono A. 2004. "Penelitian Prostitusi Kota Lampung", (Online), (http://www.freelist.org/, diakses tanggal 25 Desember 2011).

Nursalam. 2003. Konsep dan penerapan metodologi penelitian ilmu keperawatan. Jakarta: Salemba Medika.

Pringgoutomo S, Himawan S, Tjarta A. 2002. Buku Ajar Patologi I (Umum). Jakarta: Sagung Seto.

Riwidikdo, Handoko. 2008. Statistik Kesehatan. Jogjakarta: Mitra Cendikia Press.

Saryono. 2009. Metodologi Penelitian Kesehatan Penuntun Praktis Bagi Pemula. Jogjakarta: Mitra Cendikia Press. 
Scorviani V, Nugroho T. 2011. Mengungkap 9 Jenis PMS (Penyakit Menular Seksual). Yogyakarta: Nuha Medika.

Suyanto, Ummi. 2008. Riset Kebidanan Metodologi dan Aplikasi. Jogjakarta: Mitra Cendikia Press.

Wawan A, M Dewi. 2010. Teori pengukuran pengetahuan, sikap, dan perilaku manusia. Yogyakarta: Nuha Medika.

Widoyono. 2008. Penyakit Tropis Epidemiologi, Penularan, Pencegahan \& Pemberantasan. Jakarta: Erlangga.

Widyastuti Y, Rahmawati A, Purnamaningrum YE. 2009. Kesehatan reproduksi. Yogyakarta: Fitramaya. 